\title{
The relationship between organizational commitment and whistleblowing tendency: An empirical research
}

\author{
Nusret Çiftçi ${ }^{1 a}$ and Aykut Bedük ${ }^{1}$ \\ ${ }^{1}$ Faculty of Economics and Administrative Sciences, Selcuk University, Konya, Turkey
}

\begin{abstract}
The ethical position of organizations is of great importance to both organizations and society in general considering people spend their considerable lifespan in organizations. It is important to sustain the determination on ethics by detecting and revealing the ethical infringements inside the organization. In this context; whistleblowing, which is a concept deriving from the field of organizational psychology is defined as the action that informing the individuals and organizations for the on-going unethical and amoral activities in the organizations, has become important. The courage of individuals to report unethical, immoral or illegal activities to the authorities can be affected by the attitude of individuals towards the organization. One of the attitudes that are considered to affect that courage, which is named as whistleblowing, is organizational commitment. Organizational commitment shows the loyalty of employees to the organization. In this study it has been examined the relationship between employees' organizational commitment and tendency to reporting immoral behaviours. The sample of the study is composed of the employees of Faculty of Economics and Administrative Sciences at Selcuk University. For this empirical study, survey method has been used, and the reached sample chosen by simply random sampling is 88 employees.
\end{abstract}

\section{Introduction}

It is important for the stakeholders of both for-profit and non-profit organizations the ethical positions of organizations. People who deposit money in banks for valuation and protection, who buy food to feed healthy his/her kid, who buy a car with high security standards in order to fulfill that experience, and people who trust to international organizations and consider their work valuable to world peace are examples of these stakeholders.

There are some responsibilities to be carried out by some inner actors (top management, administrative board, board of directors, auditing professionals) or external actors (State, legal authorities, international organizations etc.) in order to protect the mentioned stakeholders by auditing the ethical environment of these organizations. However, in order to obtain the control sometimes there may be the need for specific information of the inner

\footnotetext{
${ }^{a}$ Corresponding author: nusret@selcuk.edu.tr
} 
worlds of the organizations. At this point there can be some situations in which employees reveal unethical behaviors in the organizations to the related authorities by behaving morally. Such behaviors, which are important in raising the ethical level of organizations, started to conceptualize under the concept of "whistleblowing" in the organizational behavior literature. The characteristics of individuals who have a tendency towards whistleblowing started to appear as a topic in the field of organizational psychology. Organizational commitment, job satisfaction, personal characteristics of employees are some of the subjects which are studied as factors affecting people's tendency to whistleblowing in the literature. In this study it has been investigated the relationship of organizational commitment and demographic characteristics of employees between whistleblowing tendency of them.

\section{Conceptual framework}

According to Robbins, et al. [1] organizational commitment is the identification of employees with the organization and its goals, and their will to continue their membership in the organization. Organizational commitment; is a topic which has been studied for a long time in many researches in the management literature. This study is grounded on the organizational commitment model of Allen and Meyer [2]. According to this model, organizational commitment is divided into three different components that are (1) affective commitment, (2) continuance commitment, (3) normative commitment.

At affective commitment, the employee feels himself/herself as part of the organization and establishes an emotional relation with the organization. Continuance commitment is defined as the low probability of the employee to pass to another organization or in other words due to lack of alternatives the commitment to the current organization. In normative commitment, the employee is grateful to the organization and does not find morally appropriate to leave the organization.

The concept of whistleblowing, which has not been defined with today's meaning even in the dictionaries until 1986, has been defined by Oxford English Dictionary as "to blow the whistle on (a person or thing): to ring an activity to a sharp conclusion, as if by the blast of a whistle; now usually by informing on (a person) or exposing (an irregularity or crime)". In the literature, Near and Miceli [3] defines whistleblowing as "disclosure by organization members (former or current) of illegal, immoral or illegitimate practices under the control of their employers, to persons or organizations that may be able to effect action.". In the same way whistleblower has been defined as the "individual who does the whistleblowing" [4]. Whistleblowing is a concept which derived from the referees who blow a whistle when a foul occurs [5].

Whistleblowing, without any doubt is a civil virtue behavior. Not keeping quiet towards wrong behaviors and acts inside the organization, and fighting against it is a virtue of high personal responsibility. Many times unfortunately, whistleblowers seen as conscientious objectors are object to various blames (treacherous, sneakers, spy, problematic etc.) and have been exposed to several risks (dismissed, exclusion, psychological violence, humiliation, retaliation etc.) [6]. However, what define the distinction between "whistleblowing" and spying is the legal and the ethical status of the action in the organization. This is because in order to consider an act as whistleblowing requires that act to be against the laws or moral.

Whistleblowing is divided into three components; according to the authority where it will be done, whether the whistleblower prefer to maintain privacy, and the procedures to be fulfilled. These distinctions too are divided into two components themselves. Figure 1 provides a clear picture of this distinction [7]. 


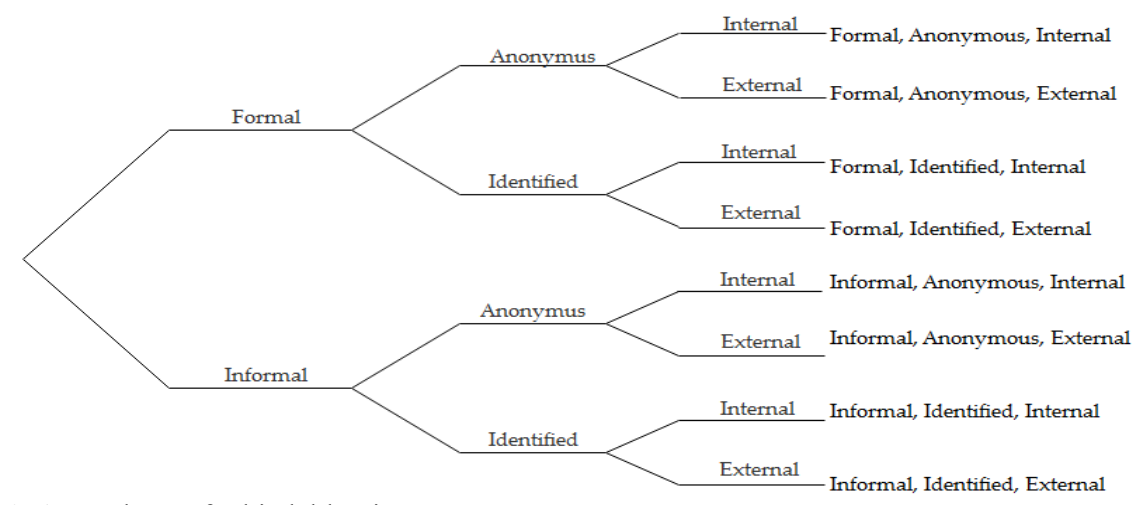

Fig. 1. A typology of whistleblowing

There is no common sense among the works studying the relationship between organizational commitment and whistleblowing. While in the works of Sims and Keenan [8] and Mesmer-Magnus and Viswesvaran [9] there is no relationship between whistleblowing tendency and organizational commitment; Miceli, et al. [10] found a positively significant relationship between whistleblowing tendency and organizational commitment. On the other hand, Somers and Casal [11] in their study found a U shaped reverse correlation between whistleblowing tendency and organizational commitment. In other words; whistleblowing tendency is seen mostly in individuals who are at the middle level of the organizational hierarchy. According to the work of Toker Gökçe [12] there exists a negative sided significant relationship between organizational commitment and normative commitment with whistleblowing tendency. In other words, individuals who are more related to the organization show a low tendency towards whistleblowing. Manjughi and Fasihizadeh [13] in their study on nurses found a strong relationship between organizational commitment and whistleblowing tendency.

\section{Method}

\subsection{Population and sample}

The population of the study is composed of the employees at the Faculty of Economics and Administrative Sciences at Selcuk University. The sample of the study is 88 and has been chosen by simply random sampling. The demographic characteristics of the participants in the sample are given at Table 1 .

Table 1. Frequency table

\begin{tabular}{llcc}
\hline & & $\mathrm{f}$ & $\%$ \\
\hline \multirow{2}{*}{ Gender } & Male & 62 & 70.5 \\
& Female & 26 & 29.5 \\
\hline \multirow{2}{*}{ Status } & Married & 60 & 68.2 \\
& Single & 28 & 31.8 \\
\hline \multirow{5}{*}{ Education } & Elementary School & 2 & 2.4 \\
& High school & 4 & 4.8 \\
& Pre-University & 8 & 9.5 \\
& University & 8 & 9.5 \\
\multirow{2}{*}{ Task type } & Master/PhD & 62 & 73.8 \\
\hline \multirow{4}{*}{ Title } & Academic staff & 64 & 72.7 \\
& Administrative Staff & 24 & 26.1 \\
\hline & Administrative Staff & 24 & 27.3 \\
& Research Assistant & 42 & 47.7 \\
& Assistant Lecturer & 3 & 3.4 \\
& Assistant Professor & 7 & 8.0 \\
\hline
\end{tabular}




\subsection{Data collection tool and reliability analysis}

This study is an empirical research. For this research, survey method was chosen as data collection tool. The questionnaire of the research has been developed by taking advantage of scales whose validity and reliability have already proven. For organizational commitment the three dimension scale developed by Allen and Meyer [2] has been used. On the other hand, for Whistleblowing the six dimension scale developed by Park, et al. [7] and translated to Turkish by Zamantılı Nayır [14] has been used. For both scales Likert scale requiring to rate the items from 1. Totally Disagree ... 7. Totally Agree has been used. Cronbach alpha values are as follows. It has been noticed that all the scales were in an acceptable level.

Table 2. Reliability analysis

\begin{tabular}{cccc}
\hline Scale & Scale Dimension & Number of Items & Cronbach Alpha \\
\hline \multirow{2}{*}{$\begin{array}{c}\text { Organizational } \\
\text { Commitment }\end{array}$} & Affective & $6(1$ item erased $)$ & 0.824 \\
& Continuance & 6 & 0.701 \\
Commitment & Normative & $6(1$ item erased $)$ & 0.815 \\
\hline \multirow{2}{*}{ Whistleblowing } & Internal & 3 & 0.904 \\
& External & 3 & 0.905 \\
& Identified & 2 & 0.898 \\
& Anonymous & 2 & 0.700 \\
& Formal & 2 & 0.834 \\
& Informal & 2 & 0.686 \\
\hline
\end{tabular}

\section{Findings}

The differences among whistleblowing tendencies according to gender are seen in Table 3 .

Table 3. The differences among whistleblowing tendencies according to gender

\begin{tabular}{|c|c|c|c|c|c|c|}
\hline & Gender & $\mathrm{N}$ & $\mathrm{X}$ & $\mathrm{SD}$ & $\mathrm{t}$ & $\mathrm{p}$ \\
\hline Internal & Male & 62 & 4.34 & 1.70 & \multirow{2}{*}{.972} & \multirow{2}{*}{.334} \\
\hline Whistleblowing & Female & 26 & 3.96 & 1.65 & & \\
\hline External & Male & 62 & 2.43 & 1.48 & \multirow{2}{*}{-.955} & \multirow{2}{*}{.342} \\
\hline Whistleblowing & Female & 26 & 2.76 & 1.42 & & \\
\hline Identified & Male & 62 & 3.02 & 1.74 & \multirow{2}{*}{.062} & \multirow{2}{*}{.951} \\
\hline Whistleblowing & Female & 26 & 3.00 & 1.48 & & \\
\hline Anonymous & Male & 62 & 2.45 & 1.38 & \multirow{2}{*}{-.346} & \multirow{2}{*}{.730} \\
\hline Whistleblowing & Female & 26 & 2.56 & 1.14 & & \\
\hline \multirow{2}{*}{ Formal Whistleblowing } & Male & 62 & 4.10 & 1.85 & \multirow{2}{*}{-.230} & \multirow{2}{*}{.819} \\
\hline & Female & 26 & 4.19 & 1.59 & & \\
\hline \multirow{2}{*}{$\begin{array}{c}\text { Informal } \\
\text { Whistleblowing }\end{array}$} & Male & 62 & 3.98 & 1.61 & \multirow{2}{*}{-2.236} & \multirow{2}{*}{$.028 *$} \\
\hline & Female & 26 & 4.79 & 1.34 & & \\
\hline \multirow{2}{*}{ Staying Silent } & Male & 62 & 2.77 & 1.60 & \multirow{2}{*}{.350} & \multirow[t]{2}{*}{.727} \\
\hline & Female & 26 & 2.63 & 1.63 & & \\
\hline
\end{tabular}

\footnotetext{
$* \mathrm{p}<, 05$
} 
According to Table 3, the whistleblowing type that shows difference according to the gender is informal whistleblowing. The tendency for whistleblowing of female participants in the sample is significantly more than the tendency of male participants. In other words, female employees do report the unethical behaviors in the organization without having a tendency to follow specific procedures.

The differences among whistleblowing tendencies according to task type are according to the values in Table 4 .

Table 4. The differences among whistleblowing tendencies according to task type

\begin{tabular}{|c|c|c|c|c|c|c|}
\hline & Task type & $\mathrm{N}$ & $\mathrm{X}$ & SD & $\mathrm{t}$ & $\mathrm{P}$ \\
\hline \multirow{2}{*}{ Internal Whistleblowing } & Academic & 64 & 4.24 & 1.75 & \multirow{2}{*}{-.016} & \multirow{2}{*}{.987} \\
\hline & Administrative & 24 & 4.25 & 1.54 & & \\
\hline \multirow{2}{*}{ External Whistleblowing } & Academic & 64 & 2.75 & 1.48 & \multirow{2}{*}{2.424} & \multirow{2}{*}{$.019^{*}$} \\
\hline & Administrative & 24 & 1.97 & 1.26 & & \\
\hline \multirow{2}{*}{ Identified Whistleblowing } & Academic & 64 & 2.93 & 1.69 & \multirow{2}{*}{-1.041} & \multirow{2}{*}{.301} \\
\hline & Administrative & 24 & 3.35 & 1.54 & & \\
\hline \multirow{2}{*}{ Anonymous Whistleblowing } & Academic & 64 & 2.61 & 1.34 & \multirow{2}{*}{1.312} & \multirow{2}{*}{.193} \\
\hline & Administrative & 24 & 2.20 & 1.17 & & \\
\hline \multirow{2}{*}{ Formal Whistleblowing } & Academic & 64 & 4.01 & 1.74 & \multirow{2}{*}{-1.144} & \multirow{2}{*}{.256} \\
\hline & Administrative & 24 & 4.50 & 1.85 & & \\
\hline \multirow{2}{*}{ Informal Whistleblowing } & Academic & 64 & 4.32 & 1.59 & \multirow{2}{*}{.833} & \multirow{2}{*}{.404} \\
\hline & Administrative & 24 & 4.00 & 1.55 & & \\
\hline \multirow{2}{*}{ Staying Silent } & Academic & 64 & 2.65 & 1.61 & \multirow{2}{*}{-.842} & \multirow{2}{*}{.405} \\
\hline & Administrative & 24 & 2.98 & 1.61 & & \\
\hline
\end{tabular}

$* \mathrm{p}<.05$

According to Table 4, the whistleblowing type that shows difference according to the task type is external whistleblowing. The tendency for whistleblowing of academic staff participants in the sample is significantly more than the tendency of administrative staff. In other words, academic staff is more likely to report the unethical behaviors witnessing in the organization to external authorities without consulting first internal authorities than administrative staff.

Table 5. The differences among whistleblowing tendencies according to marital status

\begin{tabular}{|c|c|c|c|c|c|c|}
\hline & $\begin{array}{c}\text { Marital } \\
\text { Status }\end{array}$ & $\mathrm{N}$ & $\mathrm{X}$ & $\mathrm{SD}$ & $\mathrm{t}$ & $\mathrm{p}$ \\
\hline Internal Whistleblowing & $\begin{array}{c}\text { Married } \\
\text { Single }\end{array}$ & $\begin{array}{l}60 \\
28\end{array}$ & $\begin{array}{l}4.48 \\
3.69\end{array}$ & 1.71 & 2.098 & $.039^{*}$ \\
\hline External Whistleblowing & $\begin{array}{l}\text { Married } \\
\text { Single }\end{array}$ & $\begin{array}{l}60 \\
28\end{array}$ & $\begin{array}{c}2.54 \\
2.5\end{array}$ & 1.58 & 0.116 & .908 \\
\hline Identified Whistleblowing & $\begin{array}{l}\text { Married } \\
\text { Single }\end{array}$ & $\begin{array}{l}60 \\
28\end{array}$ & $\begin{array}{l}3.09 \\
2.86\end{array}$ & 1.72 & 0.616 & .540 \\
\hline Anonymous Whistleblowing & $\begin{array}{l}\text { Married } \\
\text { Single }\end{array}$ & $\begin{array}{l}60 \\
28\end{array}$ & $\begin{array}{c}2.33 \\
2.8\end{array}$ & 1.32 & -0.627 & .109 \\
\hline Formal Whistleblowing & $\begin{array}{l}\text { Married } \\
\text { Single }\end{array}$ & $\begin{array}{l}60 \\
28\end{array}$ & $\begin{array}{l}4.29 \\
3.77\end{array}$ & 1.79 & 1.3 & .197 \\
\hline Informal Whistleblowing & $\begin{array}{l}\text { Married } \\
\text { Single }\end{array}$ & $\begin{array}{l}60 \\
28\end{array}$ & $\begin{array}{l}4.04 \\
4.61\end{array}$ & 1.59 & -1.582 & .118 \\
\hline Staying Silent & $\begin{array}{l}\text { Married } \\
\text { Single }\end{array}$ & $\begin{array}{l}60 \\
28 \\
\end{array}$ & $\begin{array}{l}2.59 \\
3.02\end{array}$ & 1.66 & -1.166 & .247 \\
\hline
\end{tabular}


According to findings of the research, the whistleblowing type that shows difference according to the marital status is internal whistleblowing. According to Table 5, married employees have more significant level of tendency towards internal whistleblowing than single employees do. In other words, married employees are more likely to report the unethical behaviors witnessed in the organization to internal authorities rather than to external authorities compared to single employees. The reason for this situation could be the fact that married employees are more family-conscious and for this reason, they trust more individuals in the organization.

In Table 6 the relationship among organizational commitment and its dimensions with whistleblowing types has been analyzed by correlation method. According to this analysis, a negative significant relationship was found among organizational commitment and anonymous whistleblowing $(\mathrm{r}=-0.299, \mathrm{p}<0.01)$. Additionally, it was found a negative significant relationship between affective commitment which is one of the dimensions of organizational commitment with anonymous whistleblowing $(\mathrm{r}=-0.328, \mathrm{p}<0.01)$. Further, it was found a negative significant relationship between normative commitment which is another dimension of organizational commitment with anonymous whistleblowing ( $\mathrm{r}=$ $0.234, \mathrm{p}<0.05)$. Moreover, it was found a negative significant relationship between normative commitment and keep quiet tendency $(\mathrm{r}=-0.283, \mathrm{p}<0.01)$. The topic for the found relationships needs to be addressed according to the comment suggested by Kalayc1 [15] whether they are very weak $(0.00-0.25)$ or weak $(0.26-0.49)$. When considering the literature and the studies on the relationship among organizational commitment whistleblowing tendency we see that they produce different results compared to each other. That is why there is no common sense on this topic.

Table 6. The correlation table among organizational commitment dimensions and the types of whistleblowing

\begin{tabular}{|c|c|c|c|c|c|c|c|c|c|c|c|}
\hline & 1 & 2 & 3 & 4 & 5 & 6 & 7 & 8 & 9 & 10 & 11 \\
\hline 1. Internal WB & 1 & & & & & & & & & & \\
\hline 2. External WB & $.274^{* *}$ & 1 & & & & & & & & & \\
\hline 3. Identified WB & $.465^{* *}$ & $.533^{* *}$ & 1 & & & & & & & & \\
\hline 4. Anonymous WB & $.309^{* *}$ & $.427^{* *}$ & .185 & 1 & & & & & & & \\
\hline 5. Formal WB & $.750^{* *}$ & $.335^{* *}$ & $.611^{* *}$ & $.271^{*}$ & 1 & & & & & & \\
\hline 6. Informal WB & .018 & $.250^{*}$ & -.058 & .174 & .015 & 1 & & & & & \\
\hline 7. Staying Silent & $-.377^{* *}$ & .029 & -.150 & .108 & $-.283^{* *}$ & ${ }^{*}-.068$ & 1 & & & & \\
\hline $\begin{array}{l}\text { 8. Affective } \\
\text { Commitment }\end{array}$ & .199 & -.204 & .079 & $-.328^{* *}$ & .034 & .033 & $-.223^{*}$ & 1 & & & \\
\hline $\begin{array}{l}\text { 9. Continuance } \\
\text { Commitment }\end{array}$ & .204 & -.076 & .007 & -.171 & .077 & .03 & -.009 & $.419^{* *}$ & 1 & & \\
\hline $\begin{array}{l}\text { 10. Normative } \\
\text { Commitment }\end{array}$ & .146 & -.173 & .017 & $-.234^{*}$ & .023 & .19 & $-.283^{* *}$ & *.694** & $.489^{* *}$ & 1 & \\
\hline $\begin{array}{l}\text { 11. Organizational } \\
\text { Commitment }\end{array}$ & $.219^{*}$ & -.186 & .044 & $-.299^{* *}$ & .051 & .102 & $-.215^{*}$ & $.866^{* *}$ & $.738^{* *}$ & $.884^{* *}$ & 1 \\
\hline
\end{tabular}

\section{Results and discussion}

Whistleblowing has become an important concept in the field of organizational psychology. Whistleblowing, which means reporting unethical behaviors to the authorities, is being studied increasingly. In the researches conducted, it is frequently examined what personal characteristics and different attitudes and behaviors affect the tendency of individuals to 
whistleblowing. Among the attitude and behaviors, there are organizational commitment, organizational citizenship, and job satisfaction. In this study, it has been explored the relationship between organizational commitment and the tendency towards different types of whistleblowing. According to findings of the study, a negative relationship between organizational commitment also its two dimensions -affective commitment and normative commitment- and tendency to anonymous whistleblowing Furthermore, there was found a negative significant relationship between normative commitment and staying silent behavior. However, these relationships showed a weak correlation. It is difficult to say whether the results of the study are compatible to the literature or not. Even among the studies exploring the relationship between organizational commitment and whistleblowing there is no single unified view. However the result obtained from this study is that managers who aspire to create an ethical and fearless environment should keep their employees committed to the organization through affective and normative standpoints. Therefore, employees witnessing an unethical behavior can report to the authorities the situation without hiding their identity information instead of being quiet.

\section{References}

1. T. L. Robbins, M. D. Crino, L. D. Fredendall. An integrative model of the empowerment process. Human resource management review 12, 419-443 (2002).

2. N. J. Allen, J. P. Meyer. The measurement and antecedents of affective, continuance and normative commitment to the organization. Journal of occupational psychology 63, 1-18 (1990).

3. J. P. Near, M. P. Miceli. Organizational dissidence: The case of whistle-blowing. Journal of Business Ethics 4, 1-16, doi:10.1007/bf00382668 (1985).

4. W. Vandekerckhove. Whistleblowing And Organizational Social Responsibility. (2006).

5. F. Qusqas, B. H. Kleiner. The Difficulties Of Whistleblowers Finding Employment. Management Research News, 97-100 (2001).

6. C. C. Aktan. Organizasyonlarda Yanlış Uygulamalara Karşı Bir Sivil Erdem, Ahlaki Tepki ve Vijdani Red Davranışı: Whistleblowing. Mercek Dergisi, 1-13 (2006).

7. H. Park, J. Blenkinsopp, M. K. Oktem, U. Omurgonulsen. Cultural orientation and attitudes toward different forms of whistleblowing: A comparison of South Korea, Turkey, and the UK. Journal of Business Ethics 82, 929-939 (2008).

8. R. L. Sims, J. P. Keenan. Predictors of external whistleblowing: Organizational and intrapersonal variables. Journal of Business Ethics 17, 411-421 (1998).

9. J. R. Mesmer-Magnus, C. Viswesvaran. Whistleblowing in organizations: An examination of correlates of whistleblowing intentions, actions, and retaliation. Journal of Business Ethics 62, 277-297 (2005).

10. M. P. Miceli, J. P. Near, C. R. Schwenk. Who blows the whistle and why? Industrial \& Labor Relations Review 45, 113-130 (1991).

11. M. J. Somers, J. C. Casal. Organizational Commitment and Whistle-Blowing A Test of the Reformer and the Organization Man Hypotheses. Group \& Organization Management 19, 270-284 (1994).

12. A. Toker Gökçe. Okullarda bilgi uçurma: İş doyumu ve örgütsel bağlılık ilişkisi. Dicle Üniversitesi Ziya Gökalp Ĕ̈itim Fakültesi Dergisi 22, 261-282 (2013).

13. N. Manjughi, N. Fasihizadeh. Simple and multiple relationships between organizational commitment with Whistle-blowing in nursing profession. Interdisciplinary Journal of Contemporary Research In Business 4, 846 (2012).

14. D. Zamantılı Nayır. Kurumsal Etik ve Whistleblowing. (2012).

15. Ş. Kalaycı. SPSS uygulamalı çok değişkenli istatistik teknikleri. Vol. 6 (2014). 